Мср Оја Кринуловић*

Универзитетска библиотека

„Светозар Марковић“, Београд
001.895:676(091)

https://doi.org/10.18485/melissa.2018.17.1.ch10

Оригинални научни рад

Примљен: 27.07.2018

Прихваћен: 11.09.2018.

\title{
РАЗВОЈ ПАПИРА НА ПУТУ СВИЛЕ
}

\section{Сажетак}

Тајна израде папира стиже из Кине. Још из 200. године пре нове ере потиче најранији сачувани комад папира и описан је као паучинасто ткана свила. Документи који су касније пронађени говоре о томе да је основа за израду папира била трака од бамбуса као и свила, али то ипак није био прави папир. Прави парир је изумео је Цај Лун познат и као Ђинг Џонг, који је служио на двору цара Хо Ти-а, династија Хан, 105. године нове ере. Идеју за изум папира је добио када му је цар Хо-Ти дао задатак да реорганизује дворску библиотеку. До тада су књиге су биле писане на дрвеним таблицама повезаним међусобно тракама и заузимале су превише места. Основна идеја је била направити замену за свилу и дрвене плочице избацити из употребе. Његова смеса за папир састојала се од дрвених влакана, траве, памука или сламе, коре дрвета и рибље кости, потопљена у воду. Тај изум је у први мах дочекан са неповерењем, али касније је прихваћен. Тајна овог изума је стотинама година остала унутар граница Кине. У Европу, уметност прављења папира је стигла из арапских држава негде у средњем веку, прво у Шпанију и Италију а затим даље. Арапи су смесу за папир обогатили својим памуком и пресованим биљем.

Кључне речи: материјали који су претходили папиру, папир, развој папира, Пут свиле, Кина, Европа, Арапи

\section{Увод}

Још од настанка цивилизације, човек је имао потребу да комуницира и тражи начине како би своје мисли и поруке пренео у писани облику.

Универзитетска библиотека „Светозар Марковић“,Булевар краља Александра 71, Београд 135505

okrinulovic@unilib.rs 
Човек је писао скоро на свим материјалима који су га окруживали. Писао је по стенама, по дрвету, листовима неких биљака, костима, металу, платну и другим материјалима које би нашао у окружењу. Како је човеков ум почео да се развија тако је и човек почео да размишља. Тако он почиње да производи неке ствари које му знатно олакшавају живот. У човеку се јавља потреба за бржим и једноставнијим комуницирањем. На почетку писао је по стенама, али стена као материјал за писање није успела да задовољи човекову потребу за бржим и једноставнијим комуницирањем. Човек почиње да тражи нека друга решење, предмете који се налазе у његовој близини он почиње да обрађује за различите намене. Од земље човек почиње да прави цигле, од глине разно посуђе. Тада човек почиње да прави глинене плочице које је користио као материјал за писање (сл.1). Глинене плочице су се могле чувати, преносити, слати на удаљена места. На овом материјалу се знатно боље писало него по стени. Међутим, како је време пролазило овај материјал није више могао задовољити све потребе развијених цивилизација. Свакодневна потреба за писањем постала је велика и тако сушење и печење глинених плочица постаје значајна кочница ефикасног функционирања читавог тадашњег друштва. У древном Египту (пре 4000 година) се почео производити један нови материјал који је био знатно напреднији од глинених плочица и који је задовољавао све тадашње потребе, то је био папирус (сл.2). Папирус се добија из биљке папируса, која је расла у подручју око ријеке Нил. Папирус је имао бројне предности у односу на остале до тада коришћене материјале за писање. Лаган је и погодан за транспорт. На њему се знатно лакше писало него на осталим материјалима. Пошто је извоз папируса из Египта у то време био забрањен, у античком граду Пергамону у Малој Азији пронађен је нови материјал-пергамент (сл.3). Материјал од кога се добија пергамент је не уштављена овчија, козија и телећа кожа. Кожа се претходно чистила од длаке, затим се лужила у кречу, а потом сушила и глачала. Овај материјал био је веома погодан за писање, много савитљивији и постојанији. Због својих квалитета потиснуо је папирус из употребе. Међутим пергамент је био веома скуп материјал и због тога је човек кренуо у нове проналаске. Тада се појављује један нови материјал који због своје јефтиноће и одличне примене веома брзо 
потиснуо пергамент. То је био папир или хартија (сл.4). Папир се сматра једним од највећих проналазака људског ума.

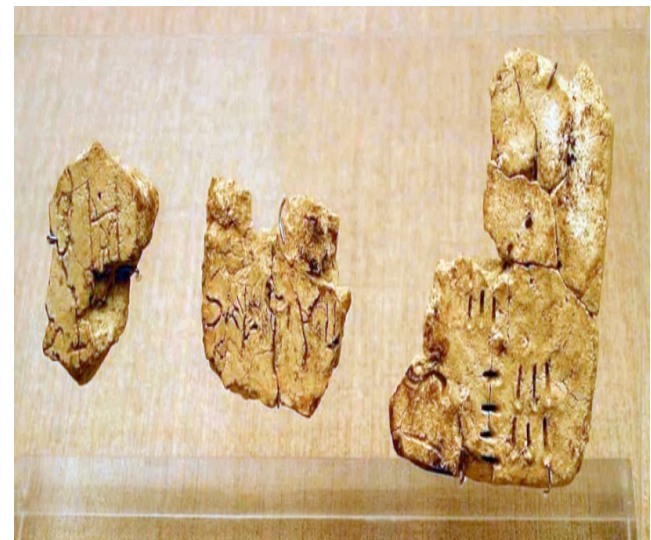

Сл.1. Глинене плочице

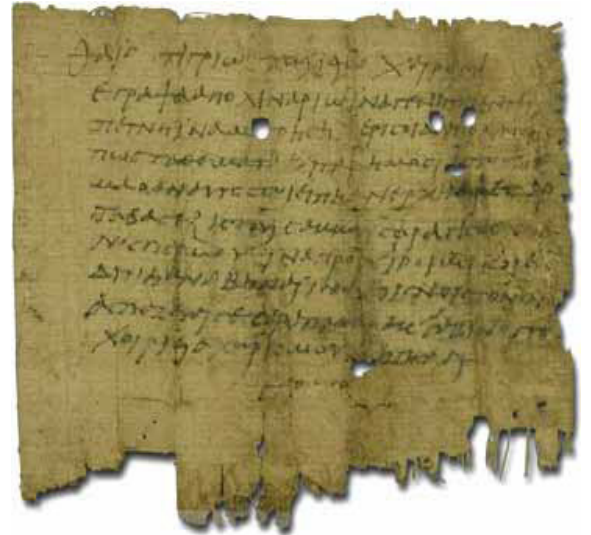

Сл.2. Папирус

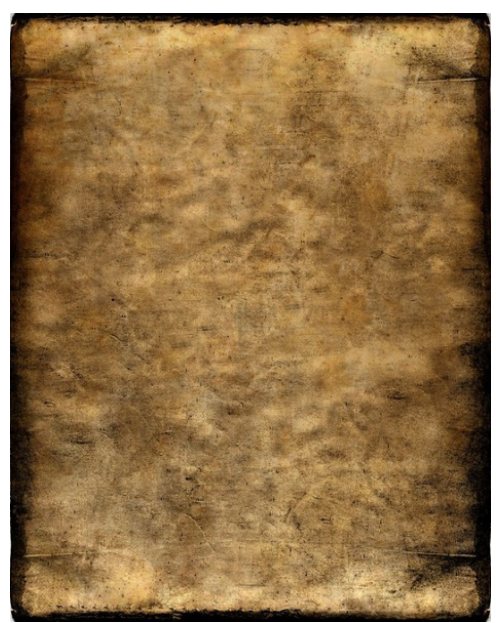

Сл.3. Пергамент
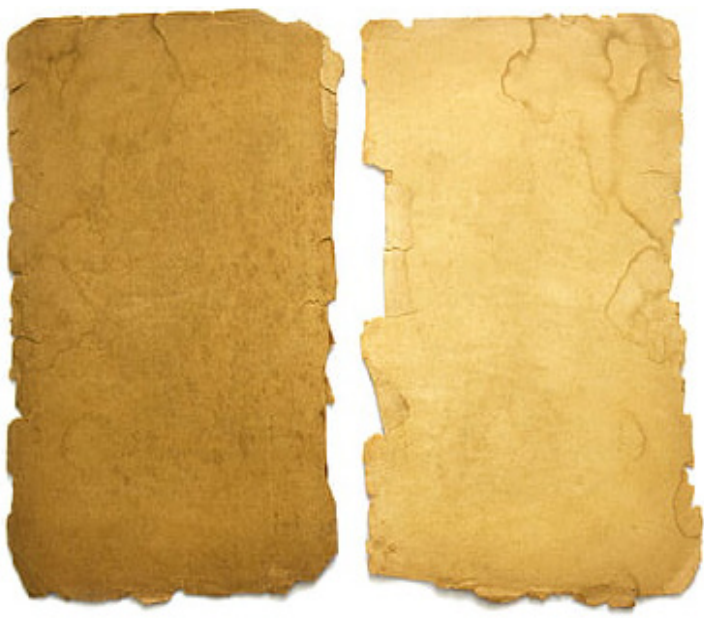

Сл.4.Папир

Процес прављења папира је развијен у Кини

Папир је изумео Цај Лун, познат у то време и као Ђинг Џонг, био је кинески царски евнух. Рођен је у време династије Источни Хан, 
у Гуијангу, округ Леијанг. Он је служио на двору цара Хо Ти-а, 105. године нове ере. Идеју за изум папира је добио када му је цар ХоТи дао задатак да реорганизује дворску библиотеку. Основна идеја је била направити замену за свилу и дрвене плочице. Његова смеса за папир састојала се од дрвених влакана, траве, памука или сламе, коре дрвета и рибље кости, потопљених у воду. Тај изум је у први мах дочекан са неповерењем, али касније је прихваћен. Цај Лун је назван „краљем папира“ и првим учитељем прављења папира. (сл.5)

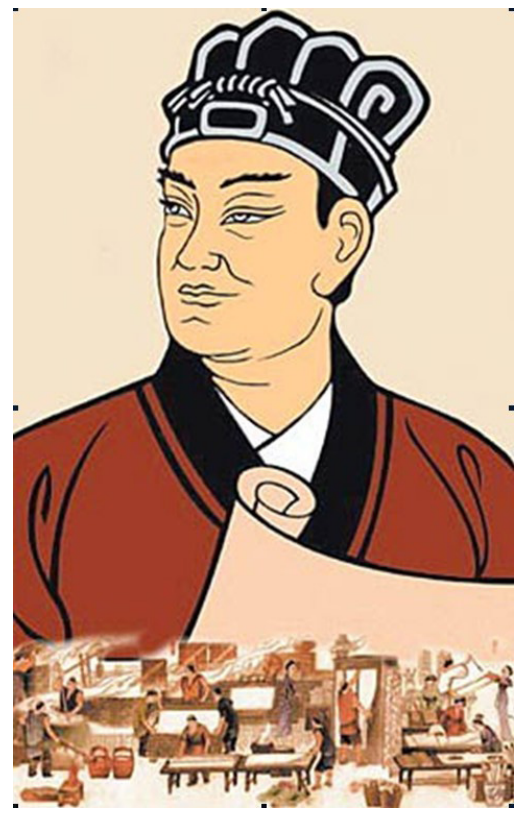

Сл.5. Цај Лун-краљ папира

Технологија прављења папира обухватала је сецкање, потапање у воду, кување папира на пари, пржење, притискање, печење и на крају излагање сунцу и киши како би избледела боја папира. Тајна овог изума је стотинама година остала унутар граница Кине.

Ово откриће Цај Лун-а је пренето у друге земље и цивилизације тек око 610. године, и то прво у Кореју, а затим 700. године у Јапан, око 750. године у арапске земље, а око 1150. године папир стиже и у Европу преко Шпаније. (сл.6) 


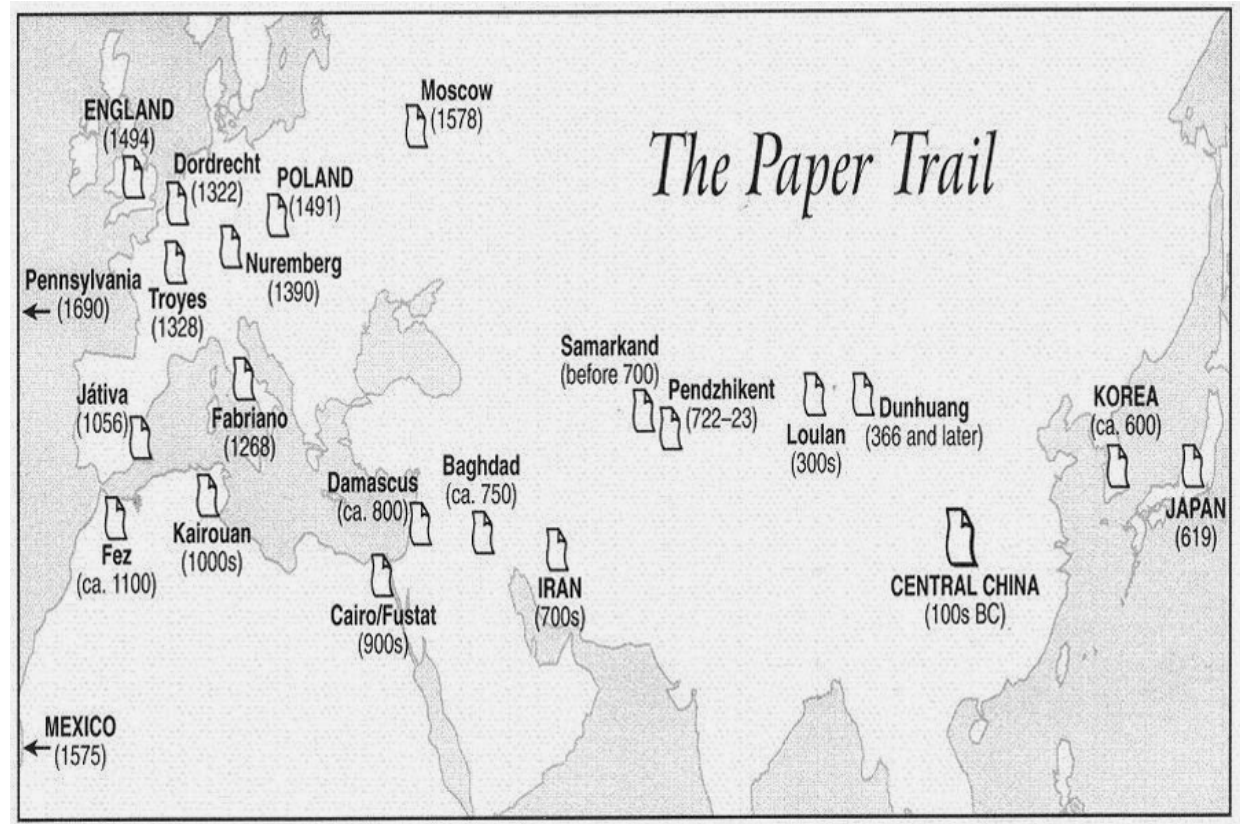

Source: Aramco World, May/June, 1999 (adapted)

Сл.6. Развојни пут папира

\section{Арапи сазнају тајну производње папира}

Кинези су 751. године, као савезници неких туркменских племена, били поражени од стране Арапа. Арапи су међу заробљеницима повели са собом неколико оних који су познавали тајну производње папира. У граду Самарканду 751. године појављује се радионица за производњу папира. То је био почетак похода папира у Европу а затим и у цели свет. Од тада почиње арапска производња папира. У Багдаду је 794. године саграђена прва велика државна радионица за производњу папира. Неколико година касније основане су радионице у Дамаску, Триполису, Хијерополису и другим градовима.

Арапи нису поседовали сировине од којих се папир добијао у Кини па су због тога морали да потраже замене за те сировине.

Главне сировине за израду папира у арапским радионицама биле су старе ланене крпе. Затим су почели користити памук и друге 
дрвенасте биљке. Временом Арапи су усавршили производњу папира. Почели су користити водене млинове, који су служили за млевење влакана, а четвртаста сита почели су израђивати од отпорнијег материјала. Арапи су усавршили и лепљење папира. У ту употребу увели су скроб од најфинијег пшеничног брашна и такво лепљење папиру је давало већу чврстоћу, трајност и сјај. У 13. веку у арапској држави су били нормирани формати папира, тачно се знало који папир и које величине се користи за одређену сврху. Арапи су увели обичај да се папир продаје у свежњу од 500 листова. Такав свежањ називао се рис. Арапи су успели да тајну производње папира сачувају веома дуг период и да је затим веома скупо продају као и остале своје производе. Арапи су основали тада највеће и најмоћније царство на свету које се простирало од Туркестана до Гибралтара. У свим тим крајевима они су подизали многе радионице за производњу папира. Најстарији папири из Маурског царства потичу из 873. године.

\section{Арапи преносе папир у Европу}

Ратним освајањем Арапи су тајну производње папира пренели у северни део Африке, Италију и Шпанију. Папир се на тим територијама почео производити на исти начин као и код Арапа. Географ и путописац Идриси у 12. веку, око 1150. године, спомиње да се у близини Валенције, у малом граду Јативи налазило неколико млинова за папир. То је најстарији податак о првој, познатој радионици папира у Европи. Након тога основане су радионице у Толеду и Валенцији.

Морало је проћи шест векова да тајна производње папира пређе из руку Кинеза у руке Арапа. Затим је требало још шест векова да та тајна дође на европско тло.

\section{Закључак}

Са развојем градова и универзитета расла је и потреба за производњом папира. 
Изумом штампарских машина започиње раздобље модерног штампарства која узрокује знатно повећање потрошње папира. Почиње се полако развијати мануфактурна производња папира, а као сировине користе се памук, лан, конопља и старе крпе.

Папир је много допринео развоју просвете и науке и сматра се једним од показатеља развоја новог доба.

\section{Литература}

Драган Бараћ. Општа историја писма. Београд: Економика, 2004

Александар Хоровић. Историја претходника хартије. Београд: Коларчев народни универзитет, 1953

Joseph Needham, Tsuen-Hsuin Tsie. Science and Civilization in China: Volume 5: Chemistry and Chemical Technology, Part 1: Paper and Printing. Cambridge University Press, 1985

Svend Dahl . Povijest knjige : od antike do danas. Zagreb : Hrvatsko bibliotekarsko društvo, 1979

Ali Akbar Velajati. Istorija kulture i civilizacije islama i Irana. Beograd: Centar za religijske nauke „Kom”, 2016

Wei Liming. The land of silk. Beijing: Foreign Languages Press, 2002

Hrvatska enciklopedija; Leksikografski zavod Miroslav Krlež. http://www.enciklopedija. hr/natuknica. aspx?id=46541 . Papir.. Digitalno izdanje

Materijali koji su prethodili hartiji - https://samoobrazovanje.rs/na-cemu-su-pisali-nasipreci-materijali-koji-su-prethodili-hartiji/ 


\title{
Oja Krinulović
}

\section{DEVELOPMENT OF THE PAPER ON THE SILK ROAD}

\begin{abstract}
Summary
The secret of making paper came from China. From the earliest 200 years before the new era, the earliest preserved piece of paper originated and is described as a woolly woven silk. Documents later found indicate that the basis for making paper was a bamboo tape as well as silk, but it was still not the right paper. The real paper was invented by Cai Lun, also known as Ying Yong, who served at the palace of the Emperor Ho-ti, Han Dynasty, in the 105th year of a new era. The idea for the invention of the paper came when the Emperor Ho-ti ordered him to reorganize the palace library. Until then, the books were written on wooden plates that were interconnected with tapes and they took up too much space. The basic idea was to make a replacement for silk and wooden tiles, to be removed from use. Its paper composition consisted of wood fibers, grass, cotton or straw, bark of wood and fish bones, immersed in water. This invention was first met with distrust, but was later accepted. The secret of this invention has remained within the boundaries of China for hundreds of years. In Europe, the art of making paper came from Arab countries sometime in the Middle Ages, first in Spain and Italy, and then in other countries. Arabs have enriched mixture of paper with their cotton and pressed herbs.
\end{abstract}

Key words: materials that preceded paper, paper, paper development, Silk Road, China, Europe, Arabs. 